\title{
TYPOGRAPHY OF BACTERIA
}

$\mathrm{A}$ $\mathrm{T}$ an informal meeting of editors of journals in which bacteriological papers appear, and some other interested persons, it was agreed that a greater uniformity in typography was desirable; the following proposals, which arose from the meeting and from subsequent discussion, may be of wider interest.

It must be made clear that those proposals are concorned solely with typography and not with the more controversial subjects of classification or nomenclature.

(1) Nomenclature. The International Code should be followed. (International Code of Nomenclature of Bacteria and Viruses: Bacteriological Code: Ames, Iowa, Iowa State University Press, 1959.)

(2) Major ranks, such as the names of orders, tribes or families, are written in roman with an initial capital; for example, Finterobacteriaceae.

(3) Binomials consisting of genus and species together are italicized, only the genus having a capital letter; for example, Staphylococcus aureus. [Note: A binomial which is considered invalid may be enclosed in quotes; for example, 'Bacillus typhosus'.]

(4) Sub-specios (varieties) are italicized, without a capital, and preceded by 'subsp.' (or 'var.') in roman; for example, Corynebacterium diphtheriae subsp. mitis.

(5) Strains are printed in roman and are capitalized only when derived from proper names; they are preceded by 'strain' in roman or may be regarded as part of a trivial name (see 9); for example, Staphylococcus aureus strain Oxford, the Oxford staphylococcus.

(6) Groups and types are printed in roman and designated by capital letters and arabic figures respectively; for example, Streptococcus pyogenes group A type 1.

(7) Generic names are italicized either when used alone to mean the whole genus as a genus or followed by 'sp.' or 'spp.' to indicate a culture which has been identified only as far as the genus. Otherwise when used either as nouns or adjectives they are regarded as trivials and printed in roman; for example, the genus Brucella ...., culture yielded Bacillus sp., some escherichias may have salmonella antigens.

(8) Specific epithets are occasionally used alone, and are usually regarded as trivials and printed in roman; for example, the strains were of the abortus type.

(9) Trivial names should be in roman type and capital. ized only when derived from proper names. (Not when names of diseases are used.) Generic names may be used trivially; for example, meningococeus, Koch-Weeks bacillus, haemophilus, spirochaete, typhoid bacillus.

(I0) Anglicized plurals may be used for trivial names to avoid classically derived forms which may appear pedantic or clumsy; for example, salmonellas, mycoplasms, actinomycetes, pseudomonads, leptospires.

(11) Hyphens should be used sparingly and never in italicized binomial (or trinomial) forms. A single word must be used to avoid confusion; for example, Salmonella choleraesuis, Bacillus pseudotuberculosisrodentium; but note: Salmonella paratyphi $B$.

(12) Abbreviations should be used with caution. Generic names may be abbreviated to a single capital letter except: in titles; in summaries; when first mentioned in the text and when any possibility of confusion could exist; for example, S. aureus (see Cowan, S. T., Science, 120, 1103; 1954); specific epithets should never be abbreviated, except possibly in tables.

(Note: Special ad hoc abbreviations may sometimes be acceptable in toxt-books or abstract journals, so long as they are clearly explained in the text.)

(13) Salmonellas present a special problem as their nomenclature is still in dispute. It is not the purpose of this communication to discuss the merits of the various proposals but to suggest appropriate typography. The following examples illustrate some of the ways in which the same culture may be described. (a) A separate species, and so written as a binomial in italics with the specific epithet in latinized form and in lowor case; for example, Salmonella londonensis (this example is after Haupt, cited in Bergey's Manual, sixth ed. The latinized form of the word 'London' should, in fact, be 'londiniensis'). (b) As above but with the specific epithet unlatinized; for example, Salmonella london. (c) A variety of a large inclusive species and so written with the epithet in lower case italies; for oxample, Salmonella kauffmanii var. londonensis. (d) A serotype of a large inclusive species and written in roman with an initial capital if derived from a proper name; for example, Salmonella kauffmannii [serotype] London. (e) A trivially named serotype written in roman throughout with an initial capital if indicated; for example, Salmonella London.

(14) Notes: (i) Specific epithets should be a single word in lower case, but serotypes, being trivials, may have more than one word and capitals where required. See pars. 9 and 11 ; for example, Salmonella saintpaul, c.f. Salmonella Saint Paul. (ii) A hybrid or bastard composed of an italicized generic name and a roman serotype cannot be defended and should not be used; for example, Salmonella London.

(15) The nomenclature of salmonellas is discussed more fully by Cowan, S. T. (Bull. Hyg., 32, 101; 1957). Here, we would merely suggest that wherever possible a single usage should be adopted for use in a single communication.

\section{A Note on the Typography of Other Micro-organisms}

(16) Fungi and protozoa. Nomenclature is governed by the international botanical and zoological codes. In general, our suggestions for bacterial typography could apply.

(17) Viruses. The nomenclature of viruses is at present being considered by the Provisional Virus Nomenclature Committee of the International Association of Micro. biological Societies. Until their findings have been accepted and approved we consider that names of viruses should be regarded as trivials. The following tentative suggestions for their typography may be helpful. (a) Viruses named after a disease should be written as separate words in lower case roman, except where the narne of the disease is derived from a proper name; for example, measles virus, poliomyelitis virus, varicellazoster virus, herpes simplex virus, Newcastlo disease virus. (b) Viruses named after a place or person should be written as separate words with an initial capital; for example, Coxsackie virus. (c) Classical or euphonious synthetic prefixes should be combined with the suffix 'virus' and written as a single word in lower case; for example, adenovirus, eytomegalovirus, echovirus, picornavirus, poliovirus. $(d)$ Unpronounceable synthetic prefixes should be written as a separate 'word' entirely in capitals; for example, LCM virus.

Among those who make these recommendations are: Sir Christopher Andrewes, formerly deputy director, National Institute for Medical Research; Dr. H. J. O'D. Burke-Gaffney, editor, Bulletin of Hygiene; Dr. S. T. Cowan, director, Central Public Health Laboratory, forrierly curator, National Collection of Type Cultures; Dr. R. M. Fry, editor, Journal of Hygiene; Dr. J. C. Kelsey, editor, Monthly Bulletin of the Ministry of Health and Public Health Laboratory Service: Section II; Prof. C. L. Oakley, editor, Journal of Pathology and Bacteriology; Mr. A. F. B. Standfast, editor, Journal for General Microbiology; Mr. G. Sykes, editor, Journal of Applied Bacteriology. 